\title{
Mega-Sporting Events in Asia - Impacts on Society, Business and Management: An Introduction
}

\author{
Harald Dolles ${ }^{\mathrm{a}}$ and Sten Söderman ${ }^{\mathrm{b}}$ \\ ${ }^{a}$ School of Management, heilbronn business school, Bahnhofstraße 1, Heilbronn 74072, Germany. \\ E-mail: dolles@hn-bs.de \\ ${ }^{\mathrm{b}}$ School of Business, Stockholm University, Stockholm SE 106 91, Sweden. \\ E-mail: sod@fek.su.se
}

Mega-sporting events today are central stages that not only feature professional athletes representing their country in competing for excellence, but also provide host nations with a universally legitimate way to present and promote their national identities and cultures on a global scale. This introduction to the special issue of Asian Business \& Management on 'Mega-sporting events in Asia' suggests insights into the emerging field of research related to mega-events and sport and summarizes the history of mega-sporting events in Asia, linking the topic to the growing importance of sports and the interest shown by national governments and cities in staging sporting events in Asia. It also offers a general framework for understanding a range of conceptual and methodological issues related to defining and measuring the impact of mega-sporting events, indicating potential directions for further research.

Asian Business \& Management (2008) 7, 147-162. doi:10.1057/abm.2008.7

Keywords: olympic games; FIFA world cup; mega-sporting events; impact analysis; Asia

\section{Mega-Sporting Events in Asia as Focus of Interest}

With the Games of the XXIX Olympiad, the host city of Beijing will step into the global spotlight. International Olympic Committee (IOC) president Jacques Rogge declared in his speech on 8 August 2007, in Tiananmen Square, celebrating the 1-year countdown to the 2008 Summer Olympic Games, that the world would be watching China and Beijing with great expectation. 'China will greet the world with an entirely new image when the Olympics open in August [2008]. Beijing and China will not only host a successful Games for the world's premier athletes, but will also provide an excellent opportunity to discover China, its history, its culture and its people, 
with China opening itself to the world in new ways' (http://english.gov.cn/ 2007-08/08/content_710677.htm, accessed 28 December 2007). But what are the expectations of the event? Taking the perspectives of athletes, coaches, officials, spectators, journalists and sponsors, who actually benefits, who is excluded? What is most needed to make it a successful gathering? What about after the event? What legacy will the 2008 Olympic Games leave to China, to Asia and the world?

We do not aim to provide answers to all these questions in this special issue of Asian Business \& Management (ABM), but would like to draw attention to the emerging field of research related to mega-events and sport (see eg Syme et al., 1989; Roche, 2000, 2006; Andranovich et al., 2001; Horne and Manzenreiter, 2002, 2004, 2006; Andranovich and Burbank, 2004; Manzenreiter and Horne, 2004; Horne, 2006; Downward and Ralston, 2006). The purpose of this introduction is, first, to frame mega-sporting events in a research context; second, to give an overview of the development of megasporting events in Asia; and third, to provide a general framework for understanding a range of conceptual and methodological issues related to defining and measuring the impact of mega-sporting events. We also address potential directions for further research in what was, until recently, seen as something of a lightweight area, compared to established fields of research (see Horne and Manzenreiter (2006), for a critical review).

The past 20 years have borne witness to a significant shift in attitude not only in research, but also in politics and industry, towards sports and the hosting of mega-sporting events. Mega-sporting events today have become central stages on which professional athletes represent their nations in competing for excellence. Furthermore, they provide host countries with a universally legitimate way to present and promote their national identities and cultures, as pointed out by Brownell (1995); Maguire (1999); Roche (2000) and others. In addition, by exploring the pathways and bidding processes towards staging a mega-sporting event (see Hiller, 2000; Andranovich et al., 2001; Harada, 2005; Ishak, 2005; Maguire, 2005b), national governments signal clearly their overall philosophy towards sport and their commitment to it. This is a rather new observable phenomenon in Asia, where sport and recreation have assumed a new relevance in recent decades, attracting attention not just from masses of people, but also from political and other quarters, including, increasingly, commercial interests. Take Singapore as an example: 'By any measure - commitment, time, financial investment or results - sports have become a way of life in 21 st-century Singapore. Through sports, we now have an important source of national identity, thanks to wide-ranging participation programmes; of national pride, as a result of high performance results at international and regional games; and of economic growth, through vibrant sports industry initiatives. The sports industry team is working on building a 
sustainable sports industry to maintain our contribution to the greater economy and to help finance our programmes into the next decade and beyond. The future holds great promise due to a strong calendar of major events, growth in sponsorship and television rights, the creation of new businesses and the anticipation of international federations in Singapore. We mean it when we say: Singapore is the city in Asia for sports and the business of sports' (http://www.ssc.gov.sg/publish/Corporate/en/about/ Sporting_Singapore_An_Overview.html, accessed 10 January 2008).

The role of sport and mega-sporting events in sustainable development should not be underestimated: 'It is an industry with unparalleled global reach and power. Globally, sport-related turnover amounts to three percent of total world economic activity. In the United Kingdom, for example, sport-related turnover equals that of the automotive and food industries. Major events such as the soccer World Cup or Formula One Grand Prix are watched around the world. Cricket attracts huge interest in South Asia, and the International Olympic Commission alone earns almost US\$2 billion from sponsorship and TV rights. At the same time, the corporate practices of this worldwide industry can and do have widespread impact, socially and environmentally' (Eric Falt, United Nation's Director of Communications, http://www.unep.org/Documents. Multilingual/Default.asp?DocumentID $=413 \&$ ArticleID $=4671 \& 1=$ en, accessed 28 December 2007).

Mainstream academic literature often suggests that sport should be studied in specialist journals, on the grounds that it is 'not generalizable'. However, sport does have a number of distinctive characteristics that may influence the way in which it internationalizes and the extent of its globalization. Sports events have uncertain outcomes, evoking thereby strongly emotional responses, such as intense loyalty, from followers. These distinctive characteristics merit discussion in this special issue of $A B M$, which is aimed at covering regional specialisms and general development by addressing mega-sporting events; the economic impacts of mega-sporting events, including budget planning and event management; the unique strategies for global expansion in sports businesses; and challenges encountered by sports and sports-governing institutions in their quest abroad. By doing so, we also respond to calls from within the sports industry as well as in sports management literature for building theoretical models that capture the international dimension of sport and mega-sporting events (eg Smith and Westerbeek, 2004; Maguire, 2005a; Close et al., 2007).

There have been some attempts to define 'wide-scale', 'special', 'hallmark' or 'mega-events' (eg among others Witt, 1988; Hall, 1989; Syme et al., 1989; Law, 1994; Roberts, 2004; Frey et al., 2007), but the definition by Roche (2000) seems most appropriate for our purposes. He suggests that mega-events are 'large-scale cultural (including commercial and sporting) events which have a 
dramatic character, mass popular appeal and international significance. They are typically organised by variable combinations of national governmental and international non-governmental organisations' (Roche, 2000: 1). In more detail and based on Roche (1994), Sola (1998) suggested that mega-events need to have an extraordinary impact on the host area in terms of one or more of the following: tourist volumes; visitor expenditures; publicity leading to a heightened awareness and a more positive image; and related infrastructural and organizational developments that substantially increase the destination's capacity and attractiveness. It is claimed, therefore, that the degree and significance of the impact of an event on the host city or region mainly determine whether the event should be termed 'mega'.

Besides placing the focus upon the consequences of an event on the host city, region or the whole nation, the media-related aspects of hosting mega-events can rarely be overlooked. Taking up this perspective presents the chance to transmit promotional messages to billions of people around the globe via television, the Internet and other developments in telecommunications that make a mega-event a truly global event (Roberts, 2004; see also Dolles and Söderman, 2005a). For example, according to FIFA (Fédération Internationale de Football Association) statistics the FIFA World Cup in Korea/Japan set a new record audience for a sports event, of 49.2 billion people worldwide in terms of viewer hours. The 2002 Final between Brazil and Germany was the most viewed match in FIFA World Cup history, with 1.1 billion individuals watching the game in 213 countries worldwide (http://www.fifa.com/en/media/index/ 0,1369,47345,00.html?articleid $=47345$, accessed 19 January 2005). Taking up both streams of argument, we highlight, in line with Horne and Manzenreiter (2006), two central features of mega-events as important for analysis: first, that mega-sporting events are deemed to have significant consequences for the host city, region or nation in which they occur; second, that they will attract considerable international media coverage.

\section{Development of Mega-Sporting Events in Asia}

Mega-sporting events are mainly connected with international multi-sports competitions such as the quadrennial Summer and Winter Olympic Games, both under the supervision of the IOC. In addition, there are also regional elite-level versions of these mega-events, like the Asian Games regulated by the Olympic Council of Asia (OCA) or the Commonwealth Games governed by the Commonwealth Games Federation (CGF). Sporting mega-events, however, also include specialist elite-level international sports competitions, such as the quadrennial FIFA World Cup in football, and regional elite-level versions 
of those sporting events, like the European Football Championship organized by UEFA (Union of European Football Associations). In the development of mega-sporting events, the year 1992 marked a turning point, as the Summer and Winter Olympic Games took place for the last time in the same year. Since then a 2-year cycle of sporting mega-events is attracting worldwide attention. The Winter Olympic Games take place the same year as the Asian Games, the Commonwealth Games and FIFA Word Cup finals. The Summer Olympic Games share the same year with the European Football Championship. The Winter Olympic Games are roughly one-quarter the size of the Olympic Summer Games in terms of athletes and events and might therefore be considered on a par with the Commonwealth Games and European Football Championships as second-tier international mega-sporting events (Matheson and Baade, 2004a; Horne and Manzenreiter, 2006).

With a view to Asia, the Games of the IIXX Olympiad were the first to be held in the region. Tokyo had been scheduled to host the Games in 1940, but the Sino-Japanese War and World War II led to their cancellation. In the 1964 Tokyo Olympics, 5,151 athletes, representing 93 countries (National Olympic Committees, NOCs), participated in 163 events (19 sports). The Tokyo Olympics were the first to use computers to record results and to be televised in colour. Satellite coverage was also provided globally for the first time, a development made possible by the first geostationary satellite, launched a year earlier. The 1964 Games were thus a fulcrum point in the global visibility and popularity of the Olympics (http://www.nhk.or.jp/strl/aboutstrl/evolutionof-tv-en/p10/index.html, accessed 13 January 2008). The Tokyo Olympics were not held as a commercial event to generate enormous fees for sponsorship and broadcasting rights, but rather as a nation-wide project on which national prestige was staked. The event became a symbol of Japan's post-war restoration. Various city infrastructures were constructed in relation to the Olympics as a national project beyond the scale of urban development. The total cost, including both direct and indirect costs, amounted to 1 trillion yen (US\$8.3 billion) (Harada, 2005). Its legacy included urban improvements to Tokyo, the nation's capital, such as capital highways, waterworks, Tokyo national airport and accommodation facilities.

South Korea was the second Asian nation to host the Olympic Games, in 1988. The Games of the XXIV Olympiad were held in Seoul, seeing 159 countries and 8,391 athletes competing in 25 sports (237 events), with 11,331 participating media representatives. Although the drug disqualification of sprinter Ben Johnson was the biggest story of this Olympics and the proven use of performance-enhancing chemicals overshadowed the Games, they were distinguished by numerous exceptional sporting performances (http://www. olympic.org/uk/games/past/index_uk.asp?OLGT =1\&OLGY = 1988, accessed 13 January 2008). 
More recently, the city of Osaka (Japan) decided to become a candidate to host the 2008 Olympic Games (which finally went to Beijing), but its candidacy failed in 2001 when it received only six votes in the first round (see Harada, 2005). In January 2008, Tokyo unveiled its blueprint for the 2016 Olympics bid, shrugging off doubts that the Games could return to Asia so soon after Beijing (http://www.shanghaidaily.com/sp/article/2008/200801/20080116/ article_345410.htm; accessed 25 January 2008). The Tokyo 2016 Bidding Committee has promised efforts to design a 'green Games' co-existing in harmony with the natural environment and an 'urban Games', with most of the Olympic venues located in the centre of the city for maximum comfort and convenience (http://en.wikipedia.org/wiki/Tokyo_2016_Olympic_bid, accessed 25 January 2008).

The 1972 Winter Olympic Games in Sapporo (Hokkaido, Japan) were the first Winter Olympics to be held outside Europe or the United States. The subject of amateurism stirred controversy when the Austrian skier star Karl Schranz was banned for receiving payment from ski product manufacturers, but full-time ice hockey players from Communist nations were allowed to compete. In total, 35 nations (NOCs) sent 1,006 winter sports athletes to 35 events (six sports) in Sapporo (http://www.olympic.org/uk/games/past/ index_uk.asp?OLGT $=2 \&$ OLGY $=1972$, accessed 14 January 2008). In 1998, the Winter Olympic Games returned to Asia after 26 years. Winter athletes numbering 2,176 from 72 nations (NOCs), competed in seven sports (68 events), observed by 8,329 media representatives in and around Nagano in the Northern Alps of Japan. For the first time, the men's ice hockey tournament was open to all, marking the acceptance of professional athletes (http://www.olympic.org/uk/games/past/index_uk.asp?OLGT $=2 \& O L G Y=$ 1998, accessed 14 January 2008).

The Asian Games owes its origins to the existence of small Asian multisports competitions since 1913. The first official Asian Games were held in 1951 in New Delhi, the capital of India, after the formal foundation of the Asian Athletic Federation in February 1949. The founding Asian NOCs agreed that the Asian Games would be held regularly every four years. Owing to regional conflicts in Asia, the NOCs decided in the 1970s to revise the constitution of the Asian Games Federation. A new association, named the Olympic Council of Asia, was created, supervising the Asian Games under the auspices of the IOC, formally starting with the 1986 Asian Games in South Korea. Beginning in New Delhi in 1951 with the participation of 11 countries and 489 athletes competing in six sports (57 events), the inaugural Asian Games developed constantly (http://www.ocasia.org/1AG.asp, accessed 14 January 2008). The 15th Asian Games in 2006 positioned the host city of Doha (Qatar), with its US\$2.6 billion investment in the global marketplace, as a 'leading new millennium destination for major international events, cultural 
relations, tourism and investment opportunities' (http://www.doha-2006.com/, accessed 14 January 2008). Observed by 1,300 accredited journalists representing 110 nationalities, in total 45 Asian nations sent 9,530 athletes to compete in 39 sports (418 events) (http://www.ocasia.org/15AG.asp, accessed 14 January 2008). Apart from the investment in sporting facilities, housing and infrastructure in Doha, this record number, greater than the Games of the XXVIII Olympiad in Athens 2004, proved that the Asian Games had become a mega-sporting event.

The Commonwealth Games are a multi-sport event held every 4 years, involving the elite athletes of the Commonwealth of Nations. The CGF is responsible for their direction and control. For the first time in its 65-year history, the XVI Commonwealth Games were held in Asia in 1998 as Malaysia played host in Kuala Lumpur. At that time a new record of 70 countries sent a total of 5,250 athletes and officials to the Kuala Lumpur Games, which featured 15 sports (212 events) (http://www.thecommonwealth.org/, accessed 13 January 2008). In 2010, the Commonwealth Games will return to Asia to be held in New Delhi, India.

With its historic decision to award the FIFA World Cup finals for the first time to Asian, and to dual, hosts, football's governing body FIFA moved strategically towards promoting football on a global scale (Baade and Matheson, 2004; Dolles and Söderman, 2005a). Japan and South Korea also had their own reasons for wanting to host the 2002 FIFA World Cup (see McCormack (2002), for a political review). The Koreans aimed at introducing the finals as a 'catalyst for peace' (Sugden and Tomlinson, 1998: 118) on the Korean peninsula, and the Japanese focused their bid on its ability to promote political stability, high technology and the country's infrastructure. This was not merely an economic matter, as 'football has always been one of the most convenient sports for serving political aims' (Butler, 2002: 43). First played in the 1930s, the World Cup determines the best football team in the world. The 2002 Korea/Japan FIFA World Cup finals represented 32 nations qualifying through competitions within each region (193 nations competed in 777 qualifying matches), being awarded a specific number of spots based on the number and quality of national teams in the region. Through successful performances of the national team, the competition provides a reliable platform for displays of national capability in sports and the instilling of national pride. The 2002 FIFA World Cup was the biggest specialist world-level sporting event in Asia to date: the 64-game tournament with its 32 participating teams was watched by an unprecedented $2,705,197$ spectators in both countries, with an accumulated worldwide TV audience of nearly 50 billion. The co-hosts Japan and South Korea spent a combined US\$4.4 billion (Japan US\$ 2,881 million; South Korea US\$ 1,513 million) in building 20 new arenas or refurbishing old arenas in 
preparation for the event (Nogawa and Mamiya, 2002; see also Manzenreiter's article in this journal).

\section{Analysing Mega-Sporting Events}

The examination of the development of mega-sporting events in Asia is a huge task. Not only has the underlying international social, economic, political and technological environment changed significantly over time, but also different motives prompt nations and cities to bid for the rights to host such events. The framework required to study them must therefore be of a widespread, general and integrated nature.

Much academic effort has been invested in the development of methods and models that measure economic impacts of mega-events (Burns et al., 1986; Syme et al., 1989; Getz, 1991, 1997; Gratton et al., 2000; Ritchie, 2000; Solberg et al., 2002; Baade and Matheson, 2002; Matheson, 2006), as well as discussions of methodology and research scope (Crompton and McKay, 1994; Crompton, 1995; Porter, 1999). Andersson, Armbrecht and Lundberg's article in this volume ('Impact of Mega-Events on the Economy') aims to provide insights into this discussion. According to the authors, there are three main different types of economic analyses addressing the issue: Input-Output Analysis, Cost-Benefit Analysis and Computable-General-Equilibrium Analysis. All three have specific advantages and disadvantages. A framework of analysis synthesizing the three approaches is suggested by Anderson et al., which might serve as a starting point for further discussion. The authors conclude with remarks regarding the economic impact of mega-events based on empirical studies, including the Games of the XXVII Olympiad hosted by Sydney (Australia) in 2000 and the FIFA Korea/Japan World Cup in 2002.

Lakshman ('The Conditions for Hosting Mega-sporting Events in Asia: Comparing Japan and India') herein examines the impact of mega-sporting events on business and economic growth in an innovative way, by applying Porter's diamond framework on the competitive advantage of nations (Porter, 1990). Specifically, the author comparatively analyses the differential impacts of mega-sporting events on social and economic development, growth and infrastructure in Japan and India. He uses as cases for study the FIFA World Cup 2002 hosted by South Korea and Japan and the ICC Cricket World Cup co-hosted by India, Pakistan and Sri Lanka in 1996. His analysis leads to the conclusion that there are significant differences in the nature and direction of the impact such mega-sporting events can have on the society and economy of nations, generalizing the differences across developed vs emerging markets of Asia.

Recent attempts have also been made to apply the 'Balanced Scorecard' approach (Kaplan and Norton, 1996) to evaluating mega-events, since the 
benefits associated with events are far-reaching and not confined solely to the economic impact analysis widely used thus far. The scorecard developed by Gratton et al. (2006) aims to organize the effects of a major sports event across four balanced perspectives: economic impact, sports development, media and sponsor evaluation, and place marketing effects. It pulls together important elements of a host's agenda, but does not claim to cover all possible impacts. With others, Frey et al. (2007) distinguish between physical, economic, environmental, social, cultural and political impacts, while Marivoet (2006) and Whitson and Horne (2006) argue that the impact of mega-events, for example, on cultural norms and values, should also be manifested clearly in research. This is further supported by the example of the founding of the Japanese professional football league as a necessary prerequisite to its bid for the FIFA World Cup. In the late 1980s foundation committee members extensively studied professional sports models in the USA and Europe, finally deciding on a model explicitly tailored to their cultural and economic preferences (Dolles and Söderman, 2005b). The major limitation of the balanced scorecard is associated with promoting multiple objectives and the need to develop measurements. The difficulty in balancing the various measures, prioritizing the perspectives and parameters/assigning weights, therefore continues to be an important area of mega-event research.

The (extended) balanced scorecard approach shows that mega-sporting events represent important impacts on society, business and management. Beside those short- and long-term impacts, we argue that mega-sporting events also represent important contextual influences. This is based on the premise that in the social world there are external forces that determine a better fit for institutions or structural alternatives. The main argument of contingency theory - one of the most favoured schools of thought within organizational theory (Donaldson, 1996a, b) - is that organizational structure is determined by certain contingencies, such as the environment (Burns and Stalker, 1961; Lawrence and Lorsch, 1967), technology (Woodward, 1965) or strategy (Chandler, 1962). Context is particularly crucial in Asian environments (Söderman, 2006). In adapting the contingency approach to research on mega-sporting events, we consider a mega-sporting event determined by, among other aspects, technology. To give an example, the sponsor revenues of mega-sporting events have grown dramatically, driven by technology and the interplay between television and sponsors' influences on the 'rules of the game'. To prove our argument, the domination of Michael Schumacher and Ferrari during the 2002-2003 Formula One season caused decline in worldwide television audience and sponsorship interest. In order to restore the uncertainty factor - already mentioned earlier as one of the distinctive characteristics of sports - and public interest in Formula One racing, the Formula One Constructors Association, together with the Formula One Administration Ltd, 
modified the rules of the competition (http://www.formula1.com/, accessed 26 January 2008).

Terjesen's article ('Venturing Beyond the Marathon: The Entrepreneurship of Ultrarunning and the IAU World Cup in Korea') takes up the contingency approach. Her study explores macro-environmental and individual factors contributing to the entrepreneurial development and professionalization of the sport, culminating in the hosting of a specialist world-class sporting event, the International Association of Ultrarunning (IAU) World Championships for $100 \mathrm{~km}$ distance in South Korea. This case-study-based research provides evidence of various macro-environmental and individual drivers of a grassroots entrepreneurial process, contextualized in Korea's sporting culture. Macroenvironmental factors include the economic crisis and Korean cultural values of camaraderie, emotional expressiveness and entrepreneurial spirit. At the individual level, self-leadership, focus, persistence, team dynamics and access to resources explain the growth of ultrarunning and the commitment to hosting the IAU World Cup.

Manzenreiter ('The "Benefits" of Hosting: Japanese Experiences from the 2002 Football World Cup') addresses political contingencies in hosting a megasporting event. The political significance of sport and staging mega-sports events for nation-states has been increasingly acknowledged in recent years (Maguire, 1993, 1999; Brownell, 1995; Roche, 2000; Xu, 2006). Manzenreiter claims that research on the political economy of hosting sport events has to a large extent focussed on case studies from the USA, where the myth of sports as an 'urban growth machine' has been most prevalent (eg Matheson and Baade, 2004b, c, 2005). Japan as a testing field has been largely overlooked, even though the country has its own distinctive history of sports-related development politics and hosting of large-scale sport events (Horne, 2004; Harada, 2002; Manzenreiter and Horne, 2005). Manzenreiter's discussion of losers and winners in the 2002 FIFA World Cup reflects on the basic question of why regional authorities might invest in sports promotion. Findings imply that local governments placed different hopes and expectations on the World Cup, depending on their environment and circumstances, for example, regions with more soft assets tended to attach less value to the event, since they envisioned less need to enhance their regional image by exploiting the cultural appeal of the World Cup. The comparison of survey data with macroeconomic figures does not establish a direct relation between the degree of involvement of regional authorities and economic performance, but demonstrates that in mature economies the business of mega-events can have little or no effect.

Looking at the overall revenues and share of the financial sources of Organizing Committees of the Olympic Games from Munich 1972 to Beijing 2008 shows that sponsorship has become the second most important source of 
revenues after television rights (Preuss, 2004) and therefore an important contingency factor in mega-sporting events. A conservative estimate by the Beijing Organizing Committee for the Olympic Games puts the revenue from sponsorship at US\$281.49 million, about 20 per cent (Preuss, 2004: 97), whereas other sources quote revenue from local sponsorship as expected to be at least double that of the Sydney or Athens Olympics, reported to reach US\$1.5 billion, due to bidding competitions and with billions more spent on advertising and promotional campaigns (http://www.cbsnews.com/stories/ 2007/08/08/world/main3144762_page2.shtml, accessed 25 January 2008). Altogether, the Olympic Games in Beijing are hardly conceivable without close collaboration with sponsor companies, which opens a new and important area of research (Farrell and Frame, 1997; Lee et al., 1997; Malfas et al., 2004; Cornwell et al., 2005; Cornwell and Coote, 2005; Söderman and Dolles, 2008). However, since multiple sponsor situations are complex and reduce sponsor distinctiveness, empirical studies in the context of mega-sporting events are needed.

Sport sponsorship is a commercial agreement by which a sponsor contractually provides financing or other support in order to establish an association between the sponsor's image, brands or products and a sport sponsorship property in return for rights to promote this association and/or for granting certain agreed direct or indirect benefits (Lagae, 2005: 13; Ukman, 2006). Hence, it is not surprising that despite being offered exclusivity, sponsoring firms are not the only companies seeking to create an association with, for example, the Olympic brand. In fact, many non-sponsors feel compelled to use this exclusive marketing platform with the hopes of reaching some cognitive association with Olympic values (Séguin and O'Reilly, 2008). Such attempts are commonly known as 'ambush marketing'.

The last article in this special issue by Preuss, Gemeinder and Séguin ('Ambush Marketing in China: Counterbalancing Olympic Sponsorship Efforts') provides empirical insights into the perception and use of ambush marketing in the Peoples Republic of China public television network CCTV5 (the official Olympic broadcaster) by examining the commercials used by various corporations during its coverage of the 2004 Olympic Games in Athens. Despite the efforts of the Beijing government to fight ambush marketing ahead of hosting the 2008 Olympic Games, the results demonstrate that concerns about the practice of ambush marketing in China must be taken seriously. An analysis of 40 commercial spots was carried out based on the 2002 Chinese 'Olympic Symbol Protection Law', as well as a comparison of ambush marketing on CCTV5 with nine other nations. Preuss et al. conclude with theoretical considerations about the general protection of Olympic sponsors' efforts and reflect on particular cultural backgrounds in China in relation to ambush marketing. 
Finally, we come back to the initial statement by IOC president Jacques Rogge, that hosting the Olympic Games provides an excellent opportunity for Beijing and China to build a global reputation. The prestige and competitive spirit associated with hosting the Olympics may leave a legacy of national pride and unity. It may also improve education and create awareness of cultural values. Already everyone in the host cities in China - from taxi drivers to Olympic volunteers - is being pressured to learn some English, and old habits like spitting in public, jumping the queues and littering are under severe discouragement in various campaigns aimed at improving the behaviour of China's citizens (http://www.cbsnews.com/stories/2007/08/08/ world/main3144762_page2.shtml, accessed 25 January 2008).

We might also observe that eight is a lucky number in China, which marks, too, the opening ceremony of the Beijing Olympic Games — on August 8th, or $8-8-08$.

\section{Acknowledgements}

Earlier versions of four of the papers in this special issue were first presented at the Workshop on 'Sport and Sports Business: Facing the Challenges of Internationalisation' at heilbronn business school, Heilbronn, in April 2007. We thank all participants for the stimulating days of discussion and gratefully acknowledge financial support from heilbronn business school and the Dieter Schwarz Foundation in hosting the event and providing travel funding to speakers. We extend our thanks to the following expert reviewers who have helped us to compile this special issue: Mark Dibben, John Horne, Arun Kumar Jain, Bruce Jaffee, Hans Jansson, Des Thwaites and Steven Jijian Wang. In the stage of final editing of the submissions, Kristina Ettrich and Anja Schneider from heilbronn business school and John Billingsley, associate editor of Asian Business \& Management, have been extremely supportive. Finally, the editors are especially grateful to Hasegawa Harukiyo, the general editor of Asian Business \& Management, for his commitment and vision in taking up our proposal for this special issue in 2006, allowing us to compile a timely issue of research to be published shortly before the opening of the Beijing Olympic Games.

\section{References}

Andranovich, G. and Burbank, M. (2004) 'Regime politics and the 2012 olympic games', California Politics and Policy 8(1): 1-18.

Andranovich, G., Burbank, M. and Heying, C. (2001) 'Olympic cities: lessons learned from megaevent politics', Journal of Urban Affairs 23(2): 113-131.

Baade, R.A. and Matheson, V.A. (2002) 'Bidding for the Olympics: Fool's Gold?', in C.P. Barros, M. Ibrahimo and S. Szymanski (eds.) Transatlantic Sport: The Comparative Economics of North American and European Sports, London: Edward Elgar, pp. 127-151.

Baade, R.A. and Matheson, V.A. (2004) 'The quest for the cup: assessing the economic impact of the world cup', Regional Studies 38(4): 343-354.

Brownell, S. (1995) Training the Body for China: Sports in the Moral Order of the People's Republic of China, Chicago: University of Chicago Press.

Burns, J.P.A., Hatch, J.H. and Mules, T.J. (eds.) (1986) The Adelaide Grand Prix: The Impact of a Special Event, Adelaide: Centre for South Australian Economic Studies. 
Burns, T. and Stalker, G.M. (1961) The Management of Innovation, London: Tavistock.

Butler, O. (2002) 'Getting the Games. Japan, South Korea and the Co-Hosted World Cup', in J. Horne and W. Manzenreiter (eds.) Japan, Korea and the 2002 World Cup, London: Routledge, pp. 43-55.

Chandler Jr., A.D. (1962) Strategy and Structure: Chapters in the History of the American Industrial Enterprise, Cambridge: MIT Press.

Close, P., Askew, D. and Xu, X. (2007) The Beijing Olympiad: The Political Economy of a Sporting Mega-Event, London: Routledge.

Cornwell, B. and Coote, L.V. (2005) 'Corporate sponsorship of a cause: the role of identification on purchase intent', Journal of Business Research 58(3): 268-276.

Cornwell, B., Weeks, S.C. and Roy, D.P. (2005) 'Sponsorship-linked marketing: opening the black box', Journal of Advertising 34(2): 21-42.

Crompton, J.L. (1995) 'Economic impact analysis of sports facilities and events: eleven sources of misapplication', Journal of Sport Management 9(1): 14-35.

Crompton, J.L. and McKay, S.L. (1994) 'Measuring the economic impacts of festivals and events: some myths, misapplications and ethical dilemmas', Festival Management \& Event Tourism 2(1): $33-43$.

Dolles, H. and Söderman, S. (2005a) 'Globalisation of sports - the case of professional football and its international management challenges', Working paper no. $05 / 1$, German Institute for Japanese Studies, Tokyo.

Dolles, H. and Söderman, S. (2005b) 'Implementing a professional football league in Japan challenges to research in international business', Working paper no. 05/6, German Institute for Japanese Studies, Tokyo.

Donaldson, L. (1996a) For Positivist Organisation Theory: Proving the Hard Core, London: Sage.

Donaldson, L. (1996b) 'The Normal Science of Structural Contingency Theory', in S.R. Clegg, C. Hardy and W.R. Nord (eds.) Handbook of Organization Studies, London: Sage, pp. 57-76.

Downward, P.M. and Ralston, R. (2006) 'The Sports Development Potentials of Sports Event Volunteering: Insights from the XVII Manchester Commonwealth Games', European Sport Management Quarterly 6(4): 333-351.

Farrell, K. and Frame, W.S. (1997) 'The value of olympic sponsorships: who is capturing the gold?', Journal of Market Focused Management 2(2): 171-182.

Frey, M., Iraldo, F. and Melis, M. (2007) 'The impact of wide-scale sport events on local development: an assessment of the XXth Torino olympics through the sustainability report', Paper presented at 'RSA, Region in focus?' international conference, April 2-5, Lisbon, Portugal.

Getz, D. (1991) Festivals, Special Events and Tourism, New York: Van Nostrand Reinhold.

Getz, D. (1997) Event Management \& Event Tourism, New York: Cognizant Communication.

Gratton, C., Dobson, N. and Shibli, S. (2000) 'The economic importance of major sporting events: a case-study of six events', Managing Leisure 5(1): 17-28.

Gratton, C., Shibli, S. and Coleman, R. (2006) 'The Economic Impact of Major Sports Events: A Review of Ten Events in the UK', in J. Horne and W. Manzenreiter (eds.) Sports Mega-Events: Social Scientific Analyses of a Global Phenomenon, Oxford: Blackwell, pp. 41-58.

Hall, C.M. (1989) 'Hallmark Tourist Events: Analysis, Definition, Methodology and Review', in G.J. Syme, B.J. Shaw, D.M. Fenton and W.S. Mueller (eds.) The Planning and Evaluation of Hallmark Events, Aldershot: Avebury, pp. 3-19.

Harada, M. (2002) Supotsuibento to keizaigaku-megaibento to homuchimu ga shuto o kawaeru [Economics of mega-sporting events - mega-sporting events and hometeams change cities], Tokyo: Heibonsha. 
Harada, M. (2005) 'Hosting a mega-sport event and its impact upon city development challenges of the city of Osaka', Paper presented at 'Comparing Sports Policy, Sports Investment and Regional Development Initiatives in the Hosting of Sports Events in East Asia and Europe', March 3-11, University of Edinburgh, UK.

Hiller, H.H. (2000) 'Mega-events, urban boosterism and growth strategies: an analysis of the objectives and legitimations of the Cape Town 2004 olympic bid', International Journal of Urban and Regional Research 24(2): 439-458.

Horne, J. (2004) 'The global game of football: the 2002 world cup and regional development in Japan', Third World Quarterly 25(7): 1233-1244.

Horne, J. (2006) 'The "Unknown Knowns" of Sports Mega-Events', in M. Robertson (ed.) Sporting Events and Event Tourism: Impacts, Plans and Opportunities, Brighton: University of Brighton Leisure Studies Association, pp. 1-17.

Horne, J. and Manzenreiter, W. (eds.) (2002) Japan, Korea and the 2002 World Cup, London: Routledge.

Horne, J. and Manzenreiter, W. (2004) 'Accounting for mega-events: forecast and actual impacts of the 2002 football world cup finals on the host countries Japan/Korea', International Review for the Sociology of Sport 39(2): 187-203.

Horne, J. and Manzenreiter, W. (2006) 'An Introduction to the Sociology of Sports Mega-Events', in J. Horne and W. Manzenreiter (eds.) Sports Mega-Events: Social Scientific Analyses of a Global Phenomenon, Oxford: Blackwell, pp. 1-24.

Ishak, M.M. (2005) 'From the commonwealth games to F1 grand prix: exploring Malaysia's initiatives in the hosting of international sports events', Paper presented at 'Comparing Sports Policy, Sports Investment and Regional Development Initiatives in the Hosting of Sports Events in East Asia and Europe', March 3-11, University of Edinburgh, UK.

Kaplan, R.S. and Norton, D.P. (1996) Translating Strategy Into Action - The Balanced Scorecard, Boston: Harvard Business School.

Lagae, W. (2005) Sports Sponsorship and Marketing Communications - A European Perspective, Harlow: Prentice-Hall.

Law, C. (1994) Urban Tourism: Attracting Visitors to Large Cities, London: Mansell.

Lawrence, P.R. and Lorsch, J.W. (1967) Organization and Environment: Managing Differentiation and Integration, New York: Free Press.

Lee, M.S., Sandler, D. and Shani, D. (1997) 'Attitudinal constructs towards sponsorships: scale development using three global sporting events', International Marketing Review 14(3): 159-169.

Maguire, J. (1993) 'Globalisation, sport and national identities: the empire strikes back?', Loisir et Société 16(2): 293-322.

Maguire, J. (1999) Global Sport: Identities, Societies, and Civilisations, Cambridge, UK: Polity Press.

Maguire, J. (2005a) 'Introduction: Power and Global Sport', in J. Maguire (ed.) Power and Global Sport: Zones of Prestige, Emulation and Resistance, London: Routledge, pp. 1-20.

Maguire, J. (2005b) 'Civilised games? Beijing 2008, Power Politics and Cultural Struggles', in J. Maguire (ed.) Power and Global Sport: Zones of Prestige, Emulation and Resistance, London: Routledge, pp. 145-158.

Malfas, M., Theodoraki, E. and Houlihan, B. (2004) 'Impacts of the olympic games as megaevents', Municipal Engineer 157(ME3): 209-220.

Manzenreiter, W. and Horne, J. (eds.) (2004) Football Goes East: Business, Culture and the People's Game in China, Japan and South Korea, London: Routledge.

Manzenreiter, W. and Horne, J. (2005) 'Public Policy, Sports Investments and Regional Development Initiatives in Contemporary Japan', in J. Nauright and K. Schimmel (eds.) The Political Economy of Sport, London: PalgraveMacmillan, pp. 152-182. 
Marivoet, S. (2006) 'UEFA Euro 2004 Portugal: The Social Construction of a Sports Mega-Event and Spectacle', in J. Horne and W. Manzenreiter (eds.) Sports Mega-Events: Social Scientific Analyses of a Global Phenomenon, Oxford: Blackwell, pp. 127-143.

Matheson, V.A. (2006) 'Mega-events: the effect of the world's biggest sporting events on local, regional and national economies', Working Paper 06-10, College of the Holy Cross, Department of Economics Faculty Research Series.

Matheson, V.A. and Baade, R.A. (2004a) 'Mega-sporting events in developing nations: playing the way to prosperity?', South African Journal of Economics 72(5): 1069-1075.

Matheson, V.A. and Baade, R.A. (2004b) 'Padding required: assessing the economic impact of the super bowl', Working Paper 04-03, Department of Economics Faculty Research Series, College of the Holy Cross.

Matheson, V.A. and Baade, R.A. (2004c) 'An Economic Slam Dunk or March Madness? Assessing the Economic Impact of the NCAA Basketball Tournament', in J. Fizel and R. Fort (eds.) The Economics of College Sports, Westport: Praeger, pp. 111-133.

Matheson, V.A. and Baade, R.A. (2005) 'Have public finance principles been shut out in financing new sports stadiums for the NFL in the United States?', Working Paper 05-11, Department of Economics Faculty Research Series, College of the Holy Cross.

McCormack, G. (2002) 'Things More Important than Football? Japan, Korea and the 2002 World Cup', in J. Horne and W. Manzenreiter (eds.) Japan, Korea and the 2002 World Cup, London: Routledge, pp. 29-42.

Nogawa, H. and Mamiya, T. (2002) 'Building Mega-Events. Critical Reflections on the 2002 World Cup Infrastructure', in J. Horne and W. Manzenreiter (eds.) Japan, Korea and the 2002 World Cup, London: Routledge, pp. 177-194.

Porter, M.E. (1990) The Competitive Advantage Of Nations, New York: Free Press.

Porter, P. (1999) 'Mega-Sporting Events as Municipal Investments: A Critique of Impact Analysis', in J. Fizel, J. Gustafson and G. Hadley (eds.) Sport Economics: Current Research, Westport: Praeger, pp. 61-73.

Preuss, H. (2004) The Economics of Staging the Olympics: A Comparison of the Games 1972-2008, Cheltenham: Edward Elgar.

Ritchie, J.R.B. (2000) 'Turning 16 days into 16 years through Olympic legacies', Event Management 6(3): 155-166.

Roberts, K. (2004) The Leisure Industries, Basingstoke: Palgrave.

Roche, M. (1994) 'Mega-events and urban policy', Annals of Tourism Research 21(1): 1-19.

Roche, M. (2000) Mega-Events and Modernity, London: Routledge.

Roche, M. (2006) 'Mega-Events and Modernity Revisited: Globalisation and the Case of the Olympics', in J. Horne and W. Manzenreiter (eds.) Sports Mega-Events: Social Scientific Analyses of a Global Phenomenon, Oxford: Blackwell, pp. 27-40.

Séguin, B. and O'Reilly, N. (2008) 'The olympic brand, ambush marketing and clutter', International Journal of Sport Management and Marketing 4(1/2): 62-84.

Smith, A. and Westerbeek, H. (2004) The Sport Business Future, Basingstoke: PalgraveMacmillan.

Söderman, S. (ed.) (2006) Emerging Multiplicity: Integration and Responsiveness in Asian Business Development, Basingstoke: PalgraveMacmillan.

Söderman, S. and Dolles, H. (2008) 'Strategic fit in international sponsorship - the case of the olympic games in Beijing 2008', International Journal of Sports Marketing and Sponsorship 9(2): 95-110.

Sola, F.E. (1998) 'The impact of mega-events', Annals of Tourism Research 25(1): 241-245.

Solberg, H.A., Andersson, T. and Shibli, S. (2002) 'An exploration of the direct economic impacts from business travellers at world championships', Event Management 7(3): 151-164.

Sugden, J. and Tomlinson, A. (1998) FIFA and the Contest for World Football: Who Rules the Peoples' Game?, Cambridge: Polity Press. 
Syme, G.J., Shaw, B.J., Fenton., D.M. and Mueller, W.S. (1989) The Planning and Evaluation of Hallmark Events, Aldershot: Avebury.

Ukman, L. (2006) IEG's Guide to Sponsorship, Chicago: IEG.

Whitson, D. and Horne, J. (2006) 'Underestimated Costs and Overestimated Benefits? Comparing the Outcomes of Sports Mega-Events in Canada and Japan', in J. Horne and W. Manzenreiter (eds.) Sports Mega-Events: Social Scientific Analyses of a Global Phenomenon, Oxford: Blackwell, pp. 73-89.

Witt, S. (1988) 'Mega events and mega attractions', Tourism Management 9(1): 76-77.

Woodward, J. (1965) Industrial Organisation: Theory and Practice, London: Oxford University Press.

Xu, X. (2006) 'Modernising China in the Olympic Spotlight: China's National Identity and the 2008 Beijing Olympiad', in J. Horne and W. Manzenreiter (eds.) Sports Mega-Events: Social Scientific Analyses of a Global Phenomenon, Oxford: Blackwell, pp. 90-107. 